\title{
Applying a Combination of AHP, ANP, and PROMETHEE Methods to Find the Optimal Location for Solar Power Plant
}

\author{
Nima Mirzaei ${ }^{*}$, Raheleh Nowzari ${ }^{2}$,

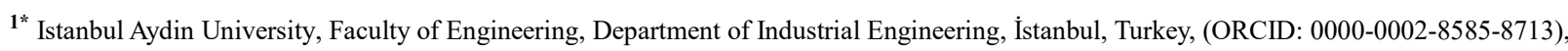 \\ nimamirzaei@aydin.edu.tr \\ 2 Istanbul Aydin University, Faculty of Engineering, Department of Mechanical Engineering, İstanbul, Turkey, (ORCID: 0000-0001-6601-4235), \\ rahelehnowzari@aydin.edu.tr
}

(International Conference on Design, Research and Development- 20 - 22 October 2021)

(DOI: 10.31590/ejosat.1039961)

ATIF/REFERENCE: Mirzaei, N. \& Nowzari, R. (2021). Applying a Combination of AHP, ANP, and PROMETHEE Methods to Find the Optimal Location for Solar Power Plant. European Journal of Science and Technology, (32), 1076-1085.

\begin{abstract}
One of the well-known renewable energy resources is solar energy which has been developed rapidly in recent years. Turkey is one of the high energy consumer countries where has a good potential for using solar power due to its geographical location. Choosing the right location is one of the main issues related to the solar power plant problem. The main objective of this study is to select the optimal location to install a solar power plant among the five cities (Antalya, Nigde, Konya, Mersin, and Isparta) in the south of Turkey, which all of them are considered as potential locations because of receiving a high amount of solar radiation. To accomplish this task, three well-known multi-criteria decision-making methods (AHP, ANP, and PROMETHEE) are used to find the best location considering six different criteria. To simplify and improve the accuracy of calculation, SuperDecisions and VisualPROMETHEE Programs are utilized for analyzing the data. The program results show that Mersin is selected as the best location and the second one is Antalya. Besides, the lowest scored city is Nigde which is considered as the least preferred alternative.
\end{abstract}

Keywords: Solar power plant, MCDM, AHP, ANP, PROMETHEE.

\section{AHP, ANP ve PROMETHEE Yöntemlerinin Bir Kombinasyonunun Uygulanması, Güneş Enerjili Elektrik Santrali için En Uygun Yerin Bulunması}

$\ddot{O} z$

Güneş enerjisi, son yıllarda hızla gelişen popüler yenilenebilir enerji kaynaklarından biridir. Türkiye, coğrafi konumu nedeniyle güneş enerjisini kullanma potansiyeli ve enerji tüketimi yüksek ülkelerden biridir. Güneş enerjili elektrik santrali sorunu ile ilgili temel konulardan biri doğru yer seci midir. Bu çalışma, Türkiye'nin güneyindeki beş şehir (Antalya, Mersin, Niğde, Isparta ve Konya) arasından, çoğunun iyi bir oranda güneş radyasyonu aldığı, güneş enerjili elektrik santrali kurmak için en uygun yeri seçmeyi amaçlamaktadır. Bu görevi gerçekleştirmek için, altı farklı kriteri göz önünde bulundurarak en iyi konumu bulmak için iyi bilinen üç çok kriterli karar verme yöntemi (AHP, ANP ve PROMETHEE) kullanılır. Hesaplamanın doğruluğunu basitleştirmek ve geliştirmek için, verilerin analizinde SuperDecisions ve VisualPROMETHEE Programları kullanılmaktadır. Çalışmanın sonuçları, Mersin'in ardından Antalya'nin en iyi alternatif olduğunu göstermektedir, Niğde ise en az tercih edilen alternatif olarak değerlendirilmek üzere en düşük puanı almıştır.

Anahtar Kelimeler: Güneş enerjili elektrik santrali, Çok kriterli karar verme , AHP, ANP, PROMETHEE

* Corresponding Author: nimamirzaei@aydin.edu.tr 


\section{Introduction}

As human population growth, the demands for energy will increase. There are various types of energy we use. The main energy resources are fossil fuels, for instance: coal, oil, and natural gas. However, fossil fuels cause environmentally unsafe compounds in the atmosphere which harm the environment and public health. Global warming and climate change are some of those negative impacts.

Renewable energies (solar, wind, etc) are other sources of energy that can be transformed into electricity that is a necessity to our daily life. Renewable energies not only reduce the progress of global warming but also won't deplete when used. As the cost of solar and wind power continue to decline significantly, the rapid growth of using them is come out (BP Outlook, 2019). Therefore, renewable energies have been appealed to great attention recently. Based on the reports of renewable energy policies, the total investment in renewable energies around the world was 279.8 billion dollars in 2017 (Finance BNE, 2018).

One of the well-known types of renewable energies is solar energy, which is one of the potential resources that provides ultimate energy and it can replace fossil fuel soon (Jung et al., 2019; Raugei et al., 2012). In addition to the environmental contribution, it is more economical compared to fossil resources (Soydan, 2021). A recent study by (Lu \& Zhao, 2018) estimated that the international share of solar energy usage will be reached to $16 \%$ by 2050 . In this respect, solar energy will be one of the main resources of energy in the near future (Campana et al., 2019).

Turkey is one of the best geographical locations which receive a high portion of solar radiation. Therefore, it has a great potential source of solar energy. However, it is considered poor in terms of fossil fuel resources (Soydan, 2021). Besides, Turkey's economic growth, industrialization, high energy demands, and increasing population forces Turkey to be more dependent on renewable energy resources. Around $50 \%$ of imported natural gas is used for electricity production over the past decade in Turkey, and it proves the high dependence on imported natural gas (Energy Report of Turkey, 2017a). According to a report that is published in 2018 by the Ministry of Energy, only 5.7\% of the power was produced from solar resources (Energy Report of Turkey, 2017b).

The total installed electricity capacity of turkey in 2016 was 78,498 MW, which has reached 88,569 MW in 2018 (TMMOB, 2018). That shows a $12.8 \%$ increase in the amount of electricity capacity, and the main reason for such an eminent growth in electricity demand are economic growth and the high rate of population (TMMOB, 2018). The total electricity demand in turkey in 2018 was $304,200 \mathrm{GWh}$, of which $69 \%$ of the electricity generation is because of the fossil fuel-based power stations (Celik \& Özgür, 2020). It is predicted that the annual average electricity demand will reach 376 billion $\mathrm{kWh}$ and billion in 2039 in 2023 and2039 respectively (BAĞCI, 2019). It is possible to conclude that, renewable energy resources such as solar energy can be the right alternative for fossil fuels for Turkey.

Regarding solar energy in Turkey, various studies have been done. Some of them are based on cost analysis, such as a study done by (Baka et al., 2019). Some other studies on solar power plants focus to determine a suitable site for the plant. For instance, in a study by (Koc et al., 2019) Multi-criteria decision-making
(MCDM) method is used to find the best location for a wind-solar site using a GIS-AHP-based approach with an application in Igdir Province, Turkey. In another study by (GEÇEN, 2019) geographic information systems (GIS) is used to find a suitable area for constructing a solar power plant in Hatay Province, Turkey. In a case study by (Colak et al., 2020a) a combination of GIS and AHP methods is employed to select the best location for a photovoltic power plant in Malatya province, Turkey. A similar study is done by (Colak et al., 2020b) in Kahramanmaras province. Although there are many types of research related to solar power plant location selection, most of them focused on the particular province.

The primary objective of this study is to find out the optimal location for a power plant by applying a combination of AHP, ANP, and PROMETHEE methods. Five cities in Turkey that receive a sufficient amount of solar radiation are considered for potential locations. Five cities are evaluated based on various criteria (using pairwise comparison) that are chosen considering the literature review and experts' opinions.

\section{Material and Method}

\subsection{Material}

In this section, the data collecting procedures are introduced. First, the potential alternatives are listed, and then the procedures of selecting effective criteria for pairwise comparison are described.

\subsubsection{Alternatives}

In this study, five different cities are selected as alternatives in the south region of Turkey. All of them are receiving a good amount of solar radiation and have sufficient area available for installing a power plant. Table 1 shows the name of cities selected as alternatives.

Table 1. Selected alternatives

\begin{tabular}{c|c}
\hline Alternatives & City \\
\hline$A 1$ & Antalya \\
\hline$A 2$ & Isparta \\
\hline$A 3$ & Konya \\
\hline$A 4$ & Mersin \\
\hline$A 5$ & Niğde \\
\hline
\end{tabular}

\subsubsection{Criteria}

One of the important subjects in MCDM is selecting the criteria. According to many types of research, the main criteria that involve solar power plant location are, geographical, environmental, and economical. The following are the list of criteria that were used by different researchers in literature to decide about the location of solar power plant:

- Solar radiation (Bakirci, 2012; Kleidon, 2018; Soydan, 2021)

- Average Temperature (Akçay \& Atak, 2018; Nowzari et al., 2015; Sánchez-Lozano et al., 2015)

- Average annual sunshine (Akçay \& Atak, 2018; Soydan, 2021; Yilmaz et al., 2015)

- $\quad$ Land cost (Al Garni \& Awasthi, 2017)

- $\quad$ Earthquake risk (Soydan, 2021) 
- $\quad$ Population density (Colak et al., 2020b; Erdoĝan \& Kaya, 2015)

Although various factors might affect the solar plant location selection problem, by considering the expert's opinions and due to data availability six of them are considered for further evaluation. The detailed information for each criterion and the data source are shown in Table 2. To have more accurate and reliable data for the first 3 criteria $\left(C_{1}, C_{2}, C_{3}\right)$ the average of the last 12 months' data is considered.

Table 2. Criteria code, description, unit, and data source

\begin{tabular}{|c|c|c|}
\hline Criteria code & Criteria description and unit & Data source \\
\hline$C_{l}$ & Solar radiation $\left(\mathrm{kWh} / \mathrm{m}^{2} /\right.$ year $)$ & https://www.mgm.gov.tr \\
\hline$C_{2}$ & Average Temperature $\left(\mathrm{C}^{\circ}\right)$ & https://www.mgm.gov.tr \\
\hline$C_{3}$ & Average annual sunshine (hrs/year) & https://www.mgm.gov.tr \\
\hline$C_{4}$ & Land cost (TL) & https://www.gib.gov.tr \\
\hline$C_{5}$ & Earthquake risk & https://www.afad.gov.tr \\
\hline$C_{6}$ & Population density & https://www.nufusu.com \\
\hline
\end{tabular}

\subsection{Method}

MCDM is considering different factors while making a decision. Various techniques are used in MCDM. There are specific steps to solve MCDM problems. The schematic demonstration of those steps are shown in Figure 1 by (Kumar et al., 2017)

Although there are several techniques in MCDM, some of the popular ones are the "Analytical Hierarchy Process" (AHP), "Analytical Network Process" (ANP), "VIekriterijumsko KOmpromisno Rangiranje" (VIKOR), "Simple Additive Weighting" (SAW), the "Technique for Order of Preference by Similarity to Ideal Solution" (TOPSIS), "Preference Ranking Organization Method for Enrichment Evaluation" (PROMETHEE), and "Elimination et Choice Translating Reality" (ELECTRE).

This study employed the combination of AHP, ANP, and PROMETHEE as an approach for the MCDM. Table 3 shows the different fields and researchers that used AHP, ANP, and PROMETHEE for the decision-making approach. In the following sections, each technique is introduced in detail.

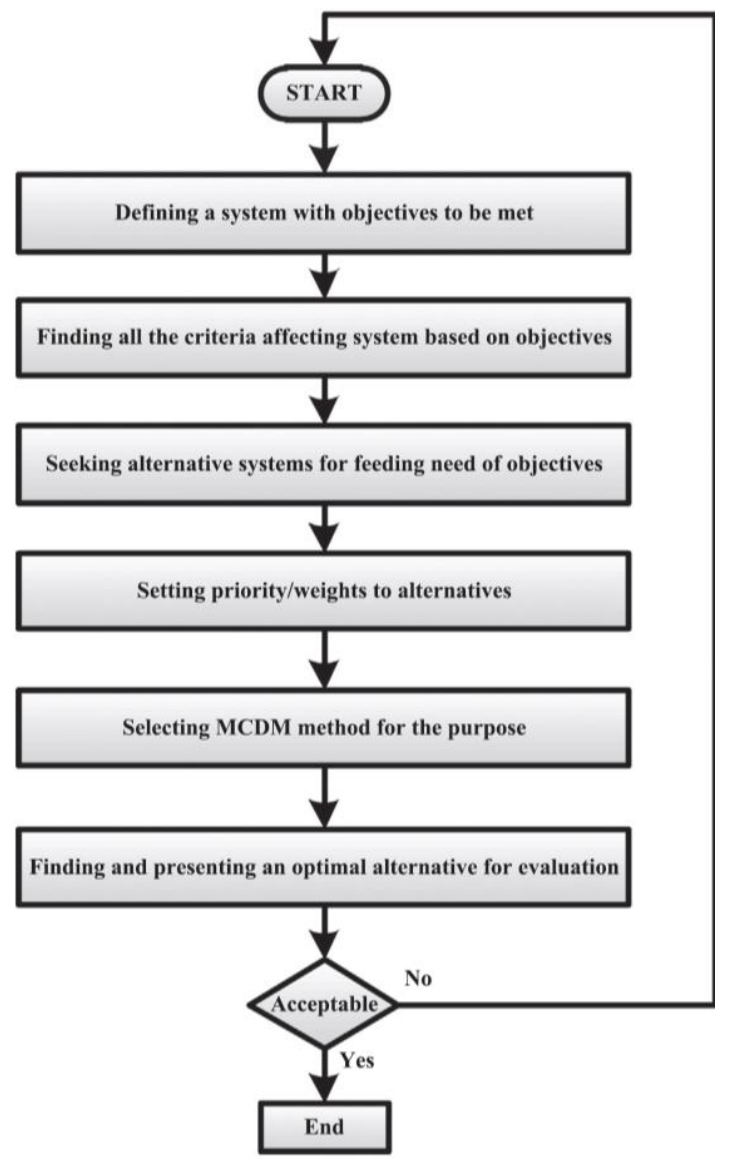

Figure 1. The procedure for solving the MCDM problem (Kumar et al., 2017) 
Table 3. AHP, ANP, and PROMETHEE methods that are used in a different area

\begin{tabular}{c|l|l}
\hline Technique & \multicolumn{1}{|c}{ Fields } & \multicolumn{1}{c}{ Researchers } \\
\hline \multirow{4}{*}{$A H P$} & Selecting a location & $\begin{array}{l}\text { (Mousavi et al., 2013) (Sennaroglu \& Varlik Celebi, 2018) (Hosseini et al., } \\
\text { 2013) (Ka, 2011) }\end{array}$ \\
\cline { 2 - 3 } & Ranking determination & $\begin{array}{l}\text { (Kang \& Lee, 2007) (Rosenbloom, 1997) (Sinuany-Stern et al., 2000) } \\
\text { (Leung \& Cao, 200) }\end{array}$ \\
\hline \multirow{4}{*}{ ANP } & \multirow{2}{*}{ Ranking determination } & $\begin{array}{l}\text { (Chung et al., 2005) (Dou et al., 2014) (Poonikom et al., 2004) (Sevkli et } \\
\text { al., 2012) (Sevkli et al., 2012) }\end{array}$ \\
\cline { 2 - 3 } & Risk management & (Akhisar, 2014) (Hasan et al., 2016) (Reza \& Majid, 2013) \\
\hline \multirow{5}{*}{ PROMETHEE } & \multirow{2}{*}{ Resorce mangement } & (Hyde \& Maier, 2006) \\
\cline { 2 - 3 } & Ranking determination & (Fontana \& Morais, 2016) \\
\cline { 2 - 3 } & (Hajkowicz \& Higgins, 2008) \\
\cline { 2 - 3 } & Risk management & $\begin{array}{l}\text { (Albadvi et al., 2006) (Kalogeras et al., 2005) (De Smet \& Guzmán, 2004) } \\
\text { (Doumpos \& Zopounidis, 2004) }\end{array}$ \\
\hline
\end{tabular}

\subsection{1. $A H P$}

The analytical hierarchy process was introduced by (Saaty, 1984) that analyzes and evaluates complex alternatives with different characteristics based on the mathematical model. It helps the decision-maker to realize and solve the problem and select the most appropriate alternative that meets the goal. The steps of applying AHP for decision-making procedure are described as follows:

Step 1: Creating pairwise decision matrix $D$. The fundamentals scale that is used to construct the pairwise comparison matrix is provided in Table 4.

Table 4. Rankig Comparison Scale (Saaty, 1990)

\begin{tabular}{c|l}
\hline $\begin{array}{c}\text { Ranking } \\
\text { number }\end{array}$ & Descriptions \\
\hline 1 & Equally peferred \\
\hline 2 & Equally to moderately \\
\hline 3 & Moderately preferred \\
\hline 4 & Moderately to strongly \\
\hline 5 & Strongly preferred \\
\hline 6 & Strongly to very strongly \\
\hline 7 & Very strongly preferred \\
\hline 8 & Very strongly to extremely \\
\hline 9 & Extremely preferred \\
\hline
\end{tabular}

In matrix $D, a_{i j}$ represent the relative importance criterion $i$ over criterion $j$, and $i, j=1,2, \ldots, m$. Thus, in matrix $D, a_{i j}=\frac{1}{a_{j i}}$ for all $i$ and $j$. For all $i=j, a_{i j}=1$.

$$
D=\left(\begin{array}{cccc}
a_{11} & a_{12} & \ldots & a_{1 m} \\
\cdot & \cdot & \ldots & \cdot \\
a_{m 1} & a_{m 2} & \ldots & a_{m m}
\end{array}\right)
$$

Step 2: Calculating the priority vector with the use of the eigenvalue method, which calculates for the primary eigenvector $w$ of matrix $D$. The importance vector indicates the weight of each criterion.

$$
D \times w=\lambda_{\max } \times w
$$

Where $\lambda_{\max }$ is the maximal eigenvalue.

Step 3: Calculate the consistency index $(C I)$ and consistency ratio $(C R)$ to check for the extent of consistency of the matrix. Note that, a matrix is considered to be inconsistent if the $C R$ value is less than 0.1 .

$$
\begin{aligned}
& C I=\frac{\lambda_{\max }-m}{m-1} \\
& C R=\frac{C I}{R I}
\end{aligned}
$$

Where random index $(R I)$ value is used for calculating consistency ratio. Table 5 depicted the value of RI for different matrix sizes.

Table 5. Random index table (Saaty \& Tran, 2007)

\begin{tabular}{c|c|c|c|c|c}
\hline Size & RI & Size & RI & Size & RI \\
\hline 1 & 0 & 6 & 1.25 & 11 & 1.52 \\
\hline 2 & 0 & 7 & 1.35 & 12 & 1.54 \\
\hline 3 & 0.52 & 8 & 1.40 & 13 & 1.56 \\
\hline 4 & 089 & 9 & 1.45 & 14 & 1.58 \\
\hline 5 & 1.11 & 10 & 1.49 & 15 & 1.59 \\
\hline
\end{tabular}

\subsection{2. $A N P$}

The analytical network process is a multi-criteria decisionmaking technique introduced by (Saaty, 1996), and it is used to drive precedence scores of absolute numbers from case-by-case assessment. It is an important tool for expressing our analysis of a decision problem. The main advantage of ANP is providing the degree of dependence between both the criteria and alternatives in the problem (Saaty, 2004).

The steps of applying ANP for the decision-making procedure are similar to AHP with some differences. In the AHP technique, there is a source node (main goal) and a sink node (alternatives) that represent alternatives. Also, there is a linear relationship structure from top to down with no feedback from the sink node (higher level) to the source node (lower level)(Saaty, 2004). Unlike AHP, in ANP there is no particular arrangement order among clusters. The network expands in all directions and 
makes it possible influence to be extended within a cluster too (Saaty, 2004). Although, in ANP the alternative cluster may or may not have feedback to other clusters.

\subsubsection{PROMETHEE}

The "preference ranking organization method for enrichment evaluation" I that is called partial ranking and II that is called complete ranking techniques were developed by (Brans, 1982). Later, several applications of these methods were used in the field of health care by (D'Avignon \& Mareschal, 1989). A few years later PROMETHEE III that is called ranking based on intervals, PROMETHEE IV (continues case), PROMETHEE V (segmentation constraints), and PROMETHEE VI which is called the representation of the human brain were developed as an extension of types I and II for different aims (Brans \& Mareschal, 2005). In the following, the general ranking procedure by PROMETHEE is explained (Brans \& Mareschal, 2005).

Let us consider the following multicriteria problem:

$$
\operatorname{Max}\left\{C_{1}(a), C_{2}(a), \ldots, C_{m}(a) \mid a \in A\right\}
$$

Where $A$ is the finite set of potential alternatives $\left\{a_{1}, a_{2}, \ldots\right.$, $\left.a_{n}\right\}$, and $\left\{C_{1}(), C_{2}(), \ldots, C_{m}()\right\}$ are a set of evaluation criteria. The aim is to find the best alternative while maximizing or minimizing criteria based on their characteristic. The evaluation matrix $E$ is represented below:

$$
E=\left[\begin{array}{cccc}
C_{1}\left(a_{1}\right) & C_{2}\left(a_{1}\right) & & C_{m}\left(a_{1}\right) \\
C_{1}\left(a_{2}\right) & C_{2}\left(a_{2}\right) & \cdots & C_{m}\left(a_{2}\right) \\
\vdots & \vdots & \ddots & \vdots \\
C_{1}\left(a_{n}\right) & C_{2}\left(a_{n}\right) & \cdots & C_{m}\left(a_{n}\right)
\end{array}\right]
$$

In addition to the basic data include in the evaluation matrix, decision-maker (DM) impression is important in the solution of a multicriteria problem. Consequently, the natural dominance relation (preferences) is required as decision aid which is defined as follows:

For $\operatorname{each}(a, b) \in A$ :

$$
\begin{aligned}
& \left\{\begin{array}{l}
\forall i: C_{i}(a) \geq C_{i}(b) \\
\exists j: C_{j}(a)>C_{j}(b)
\end{array} \Leftrightarrow a \boldsymbol{P} b,\right. \\
& \forall i: C_{i}(a)=C_{i}(b) \Leftrightarrow a \boldsymbol{I} b, \\
& \left\{\begin{array}{l}
\exists i: C_{i}(a)<C_{i}(b) \\
\exists j: C_{j}(a)>C_{j}(b)
\end{array} \Leftrightarrow a \boldsymbol{R} b,\right.
\end{aligned}
$$

Where $\boldsymbol{R}, \boldsymbol{I}$, and $\boldsymbol{P}$, stand for incomparability, preference, indifference, and preference respectively.

Another important factor that affects the ranking is the weight of the criteria. Assume that the set $\left\{w_{1}, w_{2}, \ldots, w_{m}\right\}$ represent the weight of each criterion. The weights are positive numbers, independent from the measurement unit of criteria, and the sum of the weights must be equal to one.

$$
\sum_{k=1}^{m} w_{k}=1
$$

Because pairwise comparisons are the main structure for PROMETHEE for each criterion the following function is held:

$$
P_{k}(a, b)=F_{k}\left[d_{k}(a, b)\right] \quad \forall a, b \in A
$$

Where:

$$
d_{k}(a, b)=C_{k}(a)-C_{k}(b)
$$

and for which:

$$
0 \leq P_{k}(a, b) \leq 1
$$

The aggregated preference indices can be calculated as follows:

$$
\left\{\begin{array}{l}
\pi(a, b)=\sum_{k=1}^{m} P_{k}(a, b) w_{k}, \\
\pi(b, a)=\sum_{k=1}^{m} P_{k}(b, a) w_{k} .
\end{array}\right.
$$

Where $\pi(a, b)$ presents the degree of preference of $a$ over $b$ $\operatorname{nad} \pi(b, a)$ presents how $b$ is preferred to $a$. Then, for positive and negative outranking flow the following formulas are used:

$$
\phi^{+}(a)=\frac{1}{n-1} \sum_{x \in A} \pi(a, x), \quad \phi^{-}(a)=\frac{1}{n-1} \sum_{x \in A} \pi(x, a)
$$

Finally, the net outranking flow can be calculated as their differences $\emptyset(a)=\phi^{+}(a)-\phi^{-}(a)$. The higher the net flow, the better the alternative.

\section{Results and Discussion}

SuperDecsions and VisualPROMETHEE are two programs that were used in this study as solver package to find the best alternative. The decision matrix and criteria weights were constructed by data collected from the database mentioned in Table 2 and with the help of decision-makers who are experts in renewable energy and energy management. Table 6 represents the decision matrix and weight of each criterion.

Table 6. Decision matrix and weights of criteria

\begin{tabular}{c|c|c|c|c|c|c}
\hline \multirow{2}{*}{ Alternative } & \multicolumn{7}{|c}{ Criteria and their weight } \\
\cline { 2 - 7 } & $\begin{array}{c}C_{1} \\
(0.26)\end{array}$ & $\begin{array}{c}C_{2} \\
(0.19)\end{array}$ & $\begin{array}{c}C_{3} \\
(0.19)\end{array}$ & $\begin{array}{c}C_{4} \\
(0.16)\end{array}$ & $\begin{array}{c}C_{5} \\
(0.09)\end{array}$ & $\begin{array}{c}C_{6} \\
(0.11)\end{array}$ \\
\hline$A 1$ & 1 & 0.978 & 1 & 0.124 & 0.001 & 1 \\
\hline$A 2$ & 0.932 & 0.626 & 0.880 & 0.133 & 0.002 & 0.183 \\
\hline$A 3$ & 0.933 & 0.549 & 0.880 & 0.147 & 0.003 & 0.922 \\
\hline$A 4$ & 0.981 & 1 & 0.880 & 0.671 & 0.002 & 0.739 \\
\hline$A 5$ & 0.932 & 0.568 & 0.882 & 0.526 & 0.003 & 0.149 \\
\hline
\end{tabular}

In the first step, two models were developed in SuperDecisios program for AHP and ANP techniques. Figure 2 demonstrates the developed model for AHP and Figure 3 shows the ANP model. 


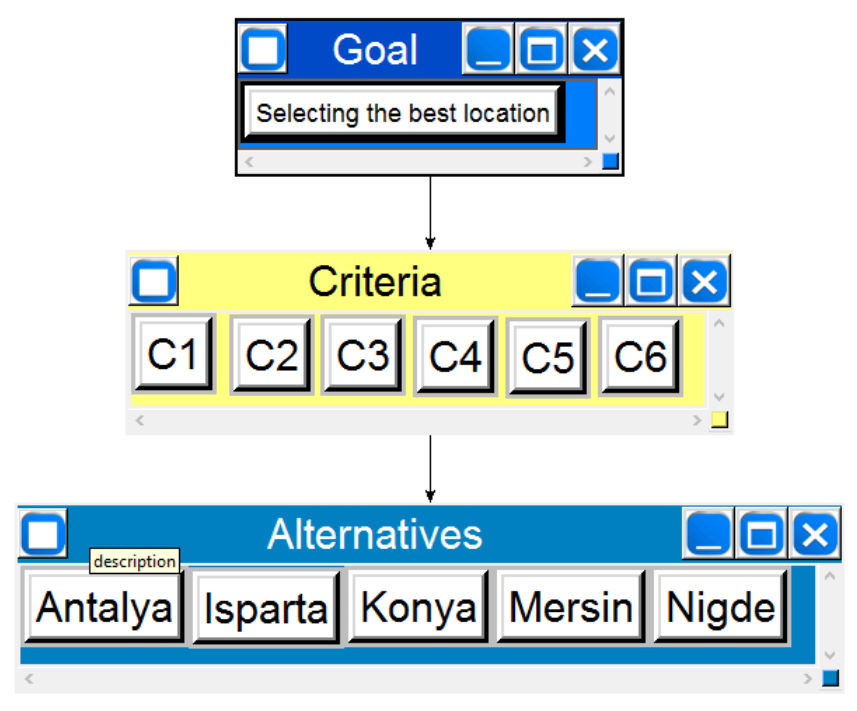

Figure 2. The AHP model

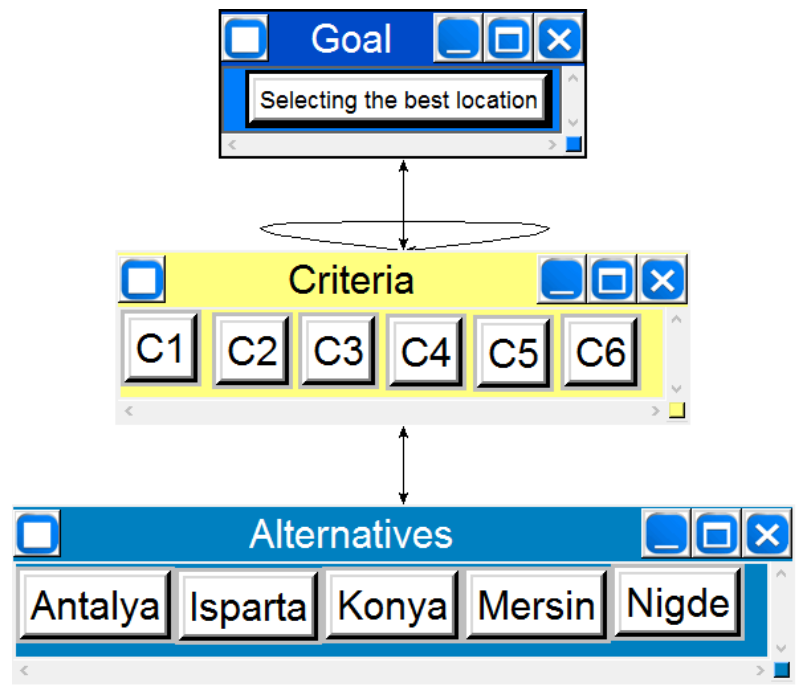

Figure 3. The ANP model

As it can differentiate between Figure 2 and Figure 3, in the AHP method there is a linear relationship structure from upper levels to lower levels with no feedback. However, in the ANP method, there are feedbacks from lower levels to higher levels, and also there are relationships within criteria.

After developing the models for AHP and ANP in the SuperDecisios program, the data for the decision matrix is entered to solve the model and rank the alternative. The results of ranking information for AHP and ANP methods are shown in Tables 7 and 8 respectively.

Table 7. AHP ranking results

\begin{tabular}{c|c|c|c|c}
\hline Alternatives & Total & Normal & Ideal & Ranking \\
\hline Antalya & 0.2311 & 0.2311 & 0.9593 & 2 \\
\hline Isparta & 0.1611 & 0.1611 & 0.6687 & 5 \\
\hline Konya & 0.1933 & 0.1933 & 0.8025 & 3 \\
\hline Mersin & 0.2409 & 0.2409 & 1 & 1 \\
\hline Nigde & 0.1737 & 0.1737 & 0.7214 & 4 \\
\hline
\end{tabular}

According to the results of the AHP method, it is possible to conclude that the best alternative is Mersin with a total score of 0.2409 followed by Antalya as the second-ranked with a score of 0.2311 .
Table 8. ANP ranking results

\begin{tabular}{c|c|c|c|c}
\hline Alternatives & Total & Normal & Ideal & Ranking \\
\hline Antalya & 0.2262 & 0.2262 & 0.9573 & 2 \\
\hline Isparta & 0.1689 & 0.1689 & 0.7147 & 5 \\
\hline Konya & 0.1891 & 0.1891 & 0.8002 & 3 \\
\hline Mersin & 0.2363 & 0.2363 & 1 & 1 \\
\hline Nigde & 0.1795 & 0.1795 & 0.7597 & 4 \\
\hline
\end{tabular}

The SuperDecision results for the ANP method are similar to AHP's results. The best alternative is Mersin, and the second one is Antalya followed by Konya, Nigde, and Isparta.

In the last step, ranking procedures were done by using Visual PROMETHEE package version 1.4.0.0. The program solution for the final ranking are shown in Table 9.

Table 9. PROMETHEE ranking results

\begin{tabular}{c|c|c|c|c}
\hline Alternatives & $\varnothing(a)$ & $\phi^{+}(a)$ & $\phi^{-}(a)$ & Ranking \\
\hline Antalya & 0.5932 & 0.7966 & 0.2034 & 1 \\
\hline Isparta & -0.1471 & 0.4264 & 0.5736 & 3 \\
\hline Konya & -0.1851 & 0.4075 & 0.59250 & 4 \\
\hline Mersin & 0.4343 & 0.7172 & 0.2828 & 2 \\
\hline Nigde & -0.6954 & 0.1532 & 0.8477 & 5 \\
\hline
\end{tabular}

As illustrated from Table 9, each alternative is given $\phi^{+}(a)$, $\phi^{-}(a)$, and $\emptyset(a)$ that means positive outranking flow, negative outranking flow, and net ranking flow respectively. An alternative with the highest value of $\emptyset(a)$ is selected as the most preferred alternative. In our case study, the best alternative is Antalya and followed by Mersin as the second one.

One of the advantages of the Visual PROMETHEE package is the graphical analysis and multidimensional presentation of the decision problem. In the following, different sensitivity analyses were performed using GAIA (Graphical Analysis for Interactive Aid).

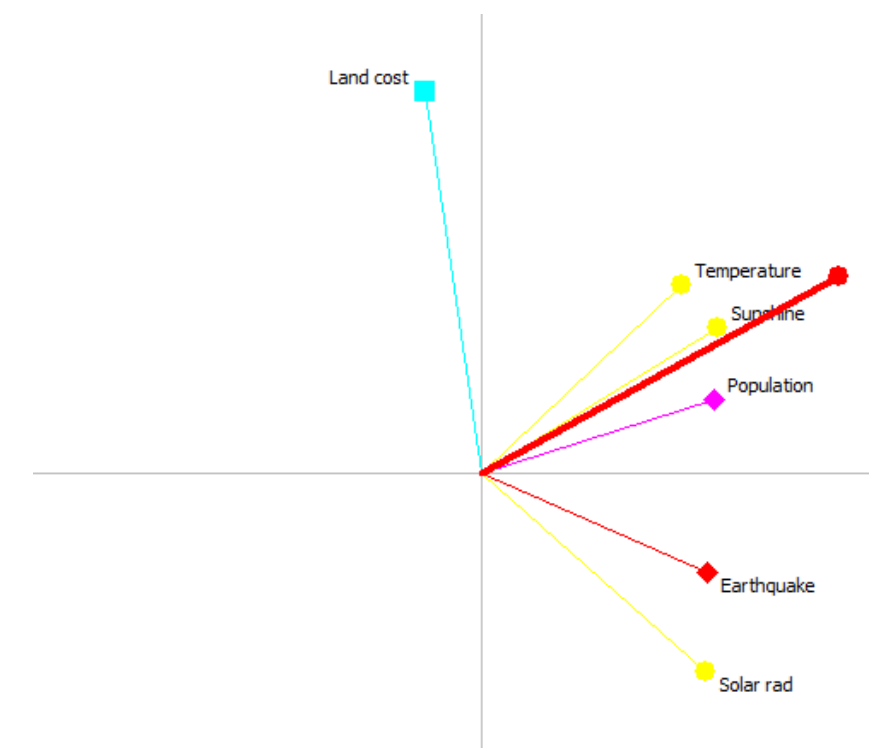

Figure 4. Criteria in the GAIA-plane

Each narrow line (axis) in figure 4 which is drawn from the center of the GAIA plane preset a criterion. The longer a line axis is, the more discriminating this criterion. for example the land 1081 
cost. Criteria expressing alike priorities are pointed in a similar or same direction. For instance, criterion 2 (average temperature) and criterion 3 (average annual sunshine) are expressing similar preferences. Oppositely, Criteria expressing contradictory relations are oriented in reverse directions of each other. The thick redline is called $\pi$ the PROMETHEE decision axis, which presents the projection of the unit vector of the weights. If $\pi$ is very long which is the case in this study, it is possible to conclude that the PROMETHEE decision axis line has strong decision power. Otherwise, if there exists a weak decision power, then it means that the criteria are highly contradicting with each other and it is difficult to select an appropriate alternative.

In the following figures, GAIA web is used as a graphical description to show the effect of the criteria in ranking the alternatives. The direction of the thick gray line (in Figures 5-9) that moves along with the criteria represents the strength and weakness of alternatives concerning the criteria. As the radius of the gray line increases, the performance of the alternative concerning that criterion increases as well. Though, when the radius decrease toward the center of the circle, it shows the weakness of alternative corresponding to that criterion.

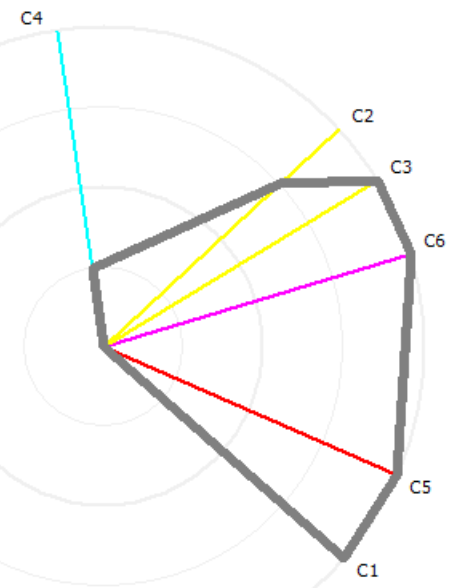

Figure 5. Antalya GAIA WEB analysis

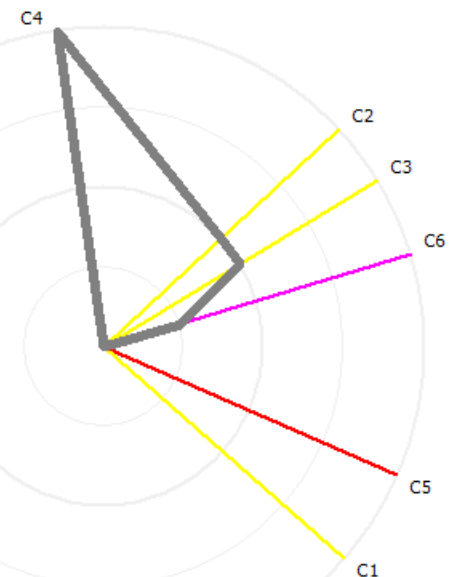

Figure 6. Isparta GAIA WEB analysis

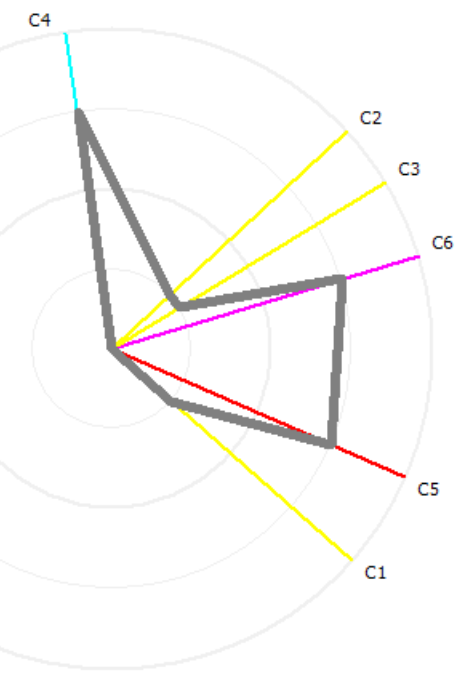

Figure 7. Konya GAIA WEB analysis

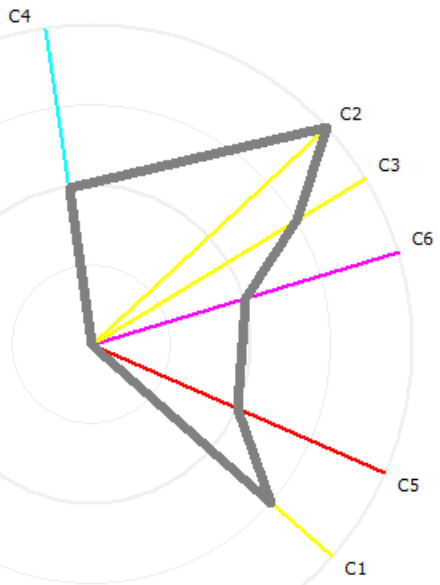

Figure 8. Mersin GAIA analysis

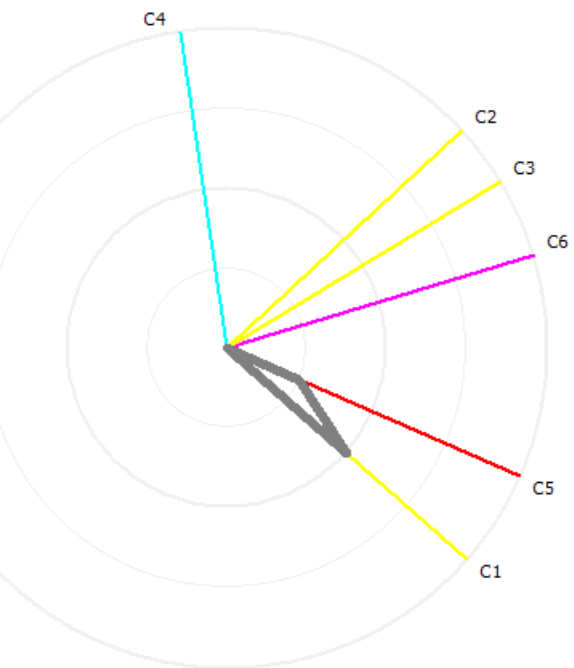

Figure 9. Nigde GAIA WEB analysis

For instance, as is demonstrated in Figure 5, Antalya has extreme performance in criteria $1,3,5,6$, and strongly on criterion 2 , and weak (performance) on criterion 4. Instead, Nigde has the lowest performance on criteria 1 and 5 and poor performance in the rest of the criteria. 


\section{Conclusions and Recommendations}

Solar energy is a sort of renewable energy resource which is obtained from the sun and it is one of the most promising ones. Turkey (because of its geographical location) is considered a potential place for the installation of a solar plant. Although there are installed solar power plants in Turkey, compared to its potential capacity, this number is small.

The main objective of this research is to use a combination of AHP, ANP, and PROMETHEE methods to find the best location of solar power plants among the five cities in Turkey that receive a sufficient amount of solar radiation. The study area includes five different cities in the south region of Turkey as alternatives. They are Antalya, Isparta, Konya, Mersin, and Niğde. Cities are evaluated and compared based on various criteria that are selected according to experts' opinions and literature review. The selected criteria are solar radiation, average temperature, average annual sunshine, land cost, earthquake risk, and population density.

To simplify and improve the accuracy of calculation, SuperDecisions and VisualPROMETHEE Programs are utilized for pairwise comparison. From the results obtained from AHP, ANP, and PROMETHEE methods, it is possible to conclude that the optimal location is Mersin, and the $2^{\text {nd }}$ location is in Antalya. Although in the PROMETHEE result Antalya became the first ranking and Mersin is the second one, in two other methods (AHP and ANP) Mersin is selected as the best alternative. Also, the GAIA is used as a graphical description to show the effect of each criterion in the pairwise comparison and ranking. Also, It assists managers or decision-makers to assess the performance of the alternative based on each criterion.

Due to the size of Turkey, and in this case, only five cities in southern Turkey are considered. In the future, it is possible to diversify the evaluation with different criteria that can be added to the model or it is possible to consider more cities as alternatives.

\section{References}

Akçay, M., \& Atak, M. (2018). Optimal Site Selection for a Solar Power Plant in Turkey Using a Hybrid AHP-TOPSIS Method. Celal Bayar Üniversitesi Fen Bilimleri Dergisi, 14(4), 413420. https://doi.org/10.18466/cbayarfbe.432432

Akhisar, I. (2014). Performance Ranking of Turkish Insurance Companies: the Anp Application. Finansal Araştırmalar ve Çallşmalar Dergisi, 6(11), 1-14. https://doi.org/10.14784/jfrs.2014117324

Al Garni, H. Z., \& Awasthi, A. (2017). Solar PV power plant site selection using a GIS-AHP based approach with application in Saudi Arabia. Applied Energy, 206(July), Energy Report of Turkeyhttps://doi.org/10.1016/j.apenergy.2017.10.024

Albadvi, A., Chaharsooghi, S. K., \& Esfahanipour, A. (2006). Decision making in stock trading: An application of PROMETHEE. European Journal of Operational Research, 177(2), 673-683. https://doi.org/10.1016/j.ejor.2005.11.022

BAĞCI, E. (2019). Renewable Energy Potential in Turkey Production, Consumption and Current Account. 101-117.

Baka, M., Manganiello, P., Soudris, D., \& Catthoor, F. (2019). A cost-benefit analysis for reconfigurable PV modules under shading. Solar Energy, 178(November 2018), 69-78. https://doi.org/10.1016/j.solener.2018.11.063

Bakirci, K. (2012). General models for optimum tilt angles of solar panels: Turkey case study. Renewable and Sustainable
Energy Reviews, 16(8),

https://doi.org/10.1016/j.rser.2012.07.009

6149-6159.

BP Outlook. (2019). BP Energy Outlook 2019 edition The Energy Outlook explores the forces shaping the global energy transition out to 2040 and the key uncertainties surrounding that. BP Energy Outlook 2019. https://www.bp.com/content/dam/bp/businesssites/en/global/corporate/pdfs/energy-economics/energyoutlook/bp-energy-outlook-2019.pdf

Brans, J. P. (1982). L'ingenierie de la decision, l'laboration d'instruments d'aidea la decision. Colloque Sur l'Aidea La Decision. Faculte Des Sciences de l'Administration, Universite Laval.

Brans, J. P., \& Mareschal, B. (2005). Promethee Methods. In Multiple Criteria Decision Analysis: State of the Art Surveys (pp. 163-186). Springer New York. https://doi.org/10.1007/0387-23081-5 5

Campana, P. E., Wästhage, L., Nookuea, W., Tan, Y., \& Yan, J. (2019). Optimization and assessment of floating and floatingtracking PV systems integrated in on- and off-grid hybrid energy systems. Solar Energy, 177, 782-795. https://doi.org/10.1016/j.solener.2018.11.045

Celik, A. N., \& Özgür, E. (2020). Review of Turkey's photovoltaic energy status: Legal structure, existing installed power and comparative analysis. Renewable and Sustainable Energy Reviews, 134, 110344. https://doi.org/10.1016/j.rser.2020.110344

Chung, S. H., Lee, A. H. I., \& Pearn, W. L. (2005). Analytic network process (ANP) approach for product mix planning in semiconductor fabricator. International Journal of Production Economics, 96(1), 15-36. https://doi.org/10.1016/j.ijpe.2004.02.006

Colak, H. E., Memisoglu, T., \& Gercek, Y. (2020a). Optimal site selection for solar photovoltaic (PV) power plants using GIS and AHP: A case study of Malatya Province, Turkey. Renewable Energy, 149, 565-576. https://doi.org/10.1016/j.renene.2019.12.078

Colak, H. E., Memisoglu, T., \& Gercek, Y. (2020b). Optimal site selection for solar photovoltaic (PV) power plants using GIS and AHP: A case study of Malatya Province, Turkey. Renewable Energy, 149, 565-576. https://doi.org/10.1016/j.renene.2019.12.078

D’Avignon, G., \& Mareschal, B. (1989). Specialization of hospital services in Quebec: An application of the promethee and GAIA methods. Mathematical and Computer Modelling, 12(10-11), 1393-1400. https://doi.org/10.1016/08957177(89)90376-2

De Smet, Y., \& Guzmán, L. M. (2004). Towards multicriteria clustering: An extension of the k-means algorithm. European Journal of Operational Research, 158(2), 390-398. https://doi.org/10.1016/j.ejor.2003.06.012

Dou, Y., Zhu, Q., \& Sarkis, J. (2014). Evaluating green supplier development programs with a grey-analytical network process-based methodology. European Journal of Operational Research, 233(2), 420-431. https://doi.org/10.1016/j.ejor.2013.03.004

Doumpos, M., \& Zopounidis, C. (2004). A multicriteria classification approach based on pairwise comparisons. European Journal of Operational Research, 158(2), 378389. https://doi.org/10.1016/j.ejor.2003.06.011

Energy Report of Turkey. (2017a). https://www.enerji.gov.tr Energy Report of Turkey. (2017b). https://www.enerji.gov.tr Erdoĝan, M., \& Kaya, I. (2015). An integrated multi-criteria 
decision-making methodology based on type-2 fuzzy sets for selection among energy alternatives in Turkey. Iranian Journal of Fuzzy Systems, 12(1), 1-25. https://doi.org/10.22111/ijfs.2015.1839

Finance BNE. (2018). Global Trends in Renewable Energy Investment Report.

Fontana, M. E., \& Morais, D. C. (2016). Decision model to control water losses in distribution networks. Producao, 26(4), 688-697. https://doi.org/10.1590/0103-6513.201815

GEÇEN, R. (2019). Determining the potential of solar power and suitable area for constructing solar power plant in hatay province. Turkish Studies-Social Sciences, Volume 14(Volume 14 Issue 6), 3031-3054. https://doi.org/10.29228/turkishstudies.30212

Hajkowicz, S., \& Higgins, A. (2008). A comparison of multiple criteria analysis techniques for water resource management. European Journal of Operational Research, 184(1), 255265. https://doi.org/10.1016/j.ejor.2006.10.045

Hasan, D., Ümit, H., \& Serhat, Y. (2016). Performance Assessment of Deposit Banks with CAMELS Analysis using Fuzzy ANP-MOORA Approaches and an Application on Turkish Banking Sector. Asian Journal of Research in Business Economics and Management, 6(2), 32. https://doi.org/10.5958/2249-7307.2016.00009.8

Hosseini, L., Tavakkoli-Moghaddam, R., Vahdani, B., Mousavi, S. M., \& Kia, R. (2013). Using the Analytical Network Process to Select the Best Strategy for Reducing Risks in a Supply Chain. Journal of Engineering (United Kingdom), 2013. https://doi.org/10.1155/2013/375628

Hyde, K. M., \& Maier, H. R. (2006). Distance-based and stochastic uncertainty analysis for multi-criteria decision analysis in Excel using Visual Basic for Applications. Environmental Modelling and Software, 21(12), 1695-1710. https://doi.org/10.1016/j.envsoft.2005.08.004

Jung, J., Han, S., \& Kim, B. (2019). Digital numerical maporiented estimation of solar energy potential for site selection of photovoltaic solar panels on national highway slopes. Applied Energy, 242, 57-68. https://doi.org/10.1016/j.apenergy.2019.03.101

Ka, B. (2011). Application of Fuzzy AHP and ELECTRE to China Dry Port Location Selection. The Asian Journal of Shipping and Logistics, 27(2), 331-353. https://doi.org/10.1016/S2092-5212(11)80015-5

Kalogeras, N., Baourakis, G., Zopounidis, C., \& Van Dijk, G. (2005). Evaluating the financial performance of agri-food firms: A multicriteria decision-aid approach. Journal of Food Engineering, 70(3), 365-371. https://doi.org/10.1016/j.jfoodeng.2004.01.039

Kang, H. Y., \& Lee, A. H. I. (2007). Priority mix planning for semiconductor fabrication by fuzzy AHP ranking. Expert Systems with Applications, 32(2), 560-570. https://doi.org/10.1016/j.eswa.2006.01.035

Kleidon, A. (2018). Energy balance. Encyclopedia of Ecology, 50-63. https://doi.org/10.1016/B978-0-12-409548-9.009271

Koc, A., Turk, S., \& Şahin, G. (2019). Multi-criteria of wind-solar site selection problem using a GIS-AHP-based approach with an application in Igdir Province/Turkey. Environmental Science and Pollution Research, 26(31), 32298-32310. https://doi.org/10.1007/s11356-019-06260-1

Kumar, A., Sah, B., Singh, A. R., Deng, Y., He, X., Kumar, P., \& Bansal, R. C. (2017). A review of multi criteria decision making (MCDM) towards sustainable renewable energy development. In Renewable and Sustainable Energy Reviews (Vol. 69, Issue June 2016, pp. 596-609). Elsevier. https://doi.org/10.1016/j.rser.2016.11.191

Leung, L. C., \& Cao, D. (2000). On consistency and ranking of alternatives in fuzzy AHP. European Journal of Operational Research, 124(1), 102-113. https://doi.org/10.1016/S03772217(99)00118-6

Lu, H., \& Zhao, W. (2018). Effects of particle sizes and tilt angles on dust deposition characteristics of a ground-mounted solar photovoltaic system. Applied Energy, 220, 514-526. https://doi.org/10.1016/j.apenergy.2018.03.095

Mousavi, S. M., Tavakkoli-Moghaddam, R., Heydar, M., \& Ebrahimnejad, S. (2013). Multi-Criteria Decision Making for Plant Location Selection: An Integrated Delphi-AHPPROMETHEE Methodology. Arabian Journal for Science and Engineering, 38(5), 1255-1268. https://doi.org/10.1007/s13369-012-0361-8

Nowzari, R., Mirzaei, N., \& Aldabbagh, L. B. Y. (2015). Finding the best configuration for a solar air heater by design and analysis of experiment. Energy Conversion and Management, 100. https://doi.org/10.1016/j.enconman.2015.04.058

Poonikom, K., O’Brien, C., \& Chansa-ngavej, C. (2004). An Application of the Analytic Network Process(ANP) for University Selection Decisions. ScienceAsia, 30(4), 317. https://doi.org/10.2306/scienceasia1513-1874.2004.30.317

Raugei, M., Fullana-i-Palmer, P., \& Fthenakis, V. (2012). The energy return on energy investment (EROI) of photovoltaics: Methodology and comparisons with fossil fuel life cycles. Energy Policy, 45, 576-582. https://doi.org/10.1016/j.enpol.2012.03.008

Reza, S., \& Majid, A. (2013). Ranking Financial Institutions Based on of Trust in online banking Using ARAS and ANP Method. International Research Journal of Applied and Basic Sciences, 6(4), 415-423.

Rosenbloom, E. S. (1997). A probabilistic interpretation of the final rankings in AHP. European Journal of Operational Research, 96(2), 371-378. https://doi.org/10.1016/S03772217(96)00049-5

Saaty, T. L. (1984). The Analytic Hierarchy Process: Decision Making in Complex Environments. In Quantitative Assessment in Arms Control (pp. 285-308). Springer US. https://doi.org/10.1007/978-1-4613-2805-6_12

Saaty, T. L. (1990). How to make a decision: The analytic hierarchy process. European Journal of Operational Research, 48(1), 9-26. https://doi.org/10.1016/03772217(90)90057-I

Saaty, T. L. (1996). Decision Making with Dependence and Feedback: The Analytic Network Process. RWS Publications, 1996, ISBN $0-9620317-9-8, \quad 370$. http://www.rwspublications.com/books/anp/decisionmaking-with-dependence-and-feedback/

Saaty, T. L. (2004). Fundamentals of the analytic network process - Dependence and feedback in decision-making with a single network. Journal of Systems Science and Systems Engineering, 13(2), 129-157. https://doi.org/10.1007/s11518-006-0158-y

Saaty, T. L., \& Tran, L. T. (2007). On the invalidity of fuzzifying numerical judgments in the Analytic Hierarchy Process. Mathematical and Computer Modelling, 46(7-8), 962-975. https://doi.org/10.1016/j.mcm.2007.03.022

Sánchez-Lozano, J. M., García-Cascales, M. S., \& Lamata, M. T. (2015). Evaluation of suitable locations for the installation of solar thermoelectric power plants. Computers and Industrial 
Engineering,

87

$343-355$.

https://doi.org/10.1016/j.cie.2015.05.028

Sennaroglu, B., \& Varlik Celebi, G. (2018). A military airport location selection by AHP integrated PROMETHEE and VIKOR methods. Transportation Research Part D: Transport and Environment, 59(January), 160-173. https://doi.org/10.1016/j.trd.2017.12.022

Sevkli, M., Oztekin, A., Uysal, O., Torlak, G., Turkyilmaz, A., \& Delen, D. (2012). Development of a fuzzy ANP based SWOT analysis for the airline industry in Turkey. Expert Systems with Applications, 39(1), 14-24. https://doi.org/10.1016/j.eswa.2011.06.047

Sinuany-Stern, Z., Mehrez, A., \& Hadad, Y. (2000). An AHP/DEA methodology for ranking decision making units. International Transactions in Operational Research, 7(2), 109-124. https://doi.org/10.1111/j.14753995.2000.tb00189.x

Soydan, O. (2021). Solar power plants site selection for sustainable ecological development in Nigde, Turkey. $S N$ Applied Sciences, 3(1). https://doi.org/10.1007/s42452-02004112-z

Spengler, T., Geldermann, J., Hähre, S., Sieverdingbeck, A., \& Rentz, O. (1998). Development of a multiple criteria based decision support system for environmental assessment of recycling measures in the iron and steel making industry. Journal of Cleaner Production, 6(1), 37-52. https://doi.org/10.1016/s0959-6526(97)00048-6

TMMOB. (2018). Türkiye' nin enerji görünümü 2018. https://www.mmo.org.tr/sites/default/files/EnerjiGorunumu2 018_1.pdf

Vaillancourt, K., \& Waaub, J. P. (2002). Environmental site evaluation of waste management facilities embedded into EUGÈNE model: A multicriteria approach. European Journal of Operational Research, 139(2), 436-448. https://doi.org/10.1016/S0377-2217(01)00365-4

Vego, G., Kučar-Dragičević, S., \& Koprivanac, N. (2008). Application of multi-criteria decision-making on strategic municipal solid waste management in Dalmatia, Croatia. Waste Management, 28(11), 2192-2201. https://doi.org/10.1016/j.wasman.2007.10.002

Yilmaz, S., Ozcalik, H. R., Kesler, S., Dincer, F., \& Yelmen, B. (2015). The analysis of different PV power systems for the determination of optimal PV panels and system installationA case study in Kahramanmaras, Turkey. Renewable and Sustainable Energy Reviews, 52, 1015-1024. https://doi.org/10.1016/j.rser.2015.07.146 